\title{
Impact of Dye-Sensitized Solar Cell Anode Preparation on Performance
}

\author{
Di Gu${ }^{1^{*}}$, Qingwei Zhang2, Qingquan $\mathrm{Wu}^{3}$, Yanji Zhu1 \\ ${ }^{1}$ College of Chemistry and Chemical Engineering, Northeast Petroleum University, Daqing, China \\ ${ }^{2}$ The Fourth Oil Extraction Plant, Daqing Oilfield Company Limited, Daqing, China \\ ${ }^{3}$ China Petroleum Engineering \& Construction Corporation, Beijing, China \\ Email: ${ }^{*}$ 48184820@qq.com
}

Received 7 June 2014; revised 23 July 2014; accepted 6 August 2014

Copyright (C) 2014 by authors and Scientific Research Publishing Inc.

This work is licensed under the Creative Commons Attribution International License (CC BY). http://creativecommons.org/licenses/by/4.0/

C) (i) Open Access

\begin{abstract}
In this paper, the suitable molecular weight of polyethylene glycol (PEG) and annealing temperature for dye-sensitized solar cells (DSSCs) anode was obtained by assessing the performance of DSSCs. The output current characteristic of the DSSCs is to explore factors that affect cell conversion efficiency and the effect of the mechanism. Experimental results show that the annealing temperature of $500^{\circ} \mathrm{C}$ and adding PEG of molecular weight 2000, the $\mathrm{TiO}_{2}$ thin film electrode $\mathrm{TiO}_{2}$ film electrode has good optical properties.
\end{abstract}

\section{Keywords}

Dye-Sensitized Solar Cells (DSSCs), Anode, Annealing Temperature, Molecular Weight of PEG

\section{Introduction}

The energy problem is the most restricting problem of current world economic development, solar energy as an inexhaustible, clean and pollution-free natural green energy, and becomes one of the most promising energies. Of currently solar cell research and application the most is silicon solar cell, but for the high cost of raw silicon cells, complex production process, improving efficiency potential is limited (the theoretical limit of the photoelectric conversion efficiency of 30\%), limiting its civilian, in an urgent need of the development of low cost solar cell.

In 1991, O’Regan et al. [1] for the first time assembled photoelectric conversion efficiency of 7.1\% - 7.9\% of the DSSCs, and created a new field of solar cell research and development. Subsequently, Gratzel et al. [2]-[4] developed a photoelectric energy conversion efficiency up to $10 \%$ - 11\% of DSSCs. As the DSSCs' relatively

\footnotetext{
*Corresponding author.
} 
low price, simple production process and potentially high photoelectric conversion efficiency, making it possible to replace the traditional silicon-based solar cells, it becomes the dominant future solar cells. The sensitized semiconductor optical anode of DSSCs plays a crucial role as a research hotspot. This paper introduced the preparation method of the anode of DSSCs, and the component parameters of two types of optical properties of anode effect are analyzed.

\section{Experimental}

\subsection{Slurry Preparation of $\mathrm{TiO}_{2} \mathrm{Sol}+\mathrm{P} 25$}

A certain amount of nano $\mathrm{TiO}_{2}$ powder is adding in $\mathrm{TiO}_{2}$ sol (nano $\mathrm{TiO}_{2}$ powder in volume in $\mathrm{TiO}_{2}$ sol was $120 \mathrm{~g} \cdot \mathrm{L}^{-1}$ ), and add a certain amount of PEG (PEG an amount of $40 \%$ by mass of titanium oxide), sufficiently stirred, ultrasonic dispersion to obtain $\mathrm{TiO}_{2}$ slurry.

\subsection{Annealing}

The coated membrane by placing the crucible in a muffle furnace at $20^{\circ} \mathrm{C} / \mathrm{min}$ at $500^{\circ} \mathrm{C}$ heated to a constant temperature for two hours, then cooled in the furnace. After hydrolysis of the intermediate product suitable high-temperature annealing was completely decomposed, residual organic matter can be completely removed, and finally completely dehydrated, only closely integrated with the substrate of titanium dioxide films.

In order to study crystalline and optical properties of $\mathrm{TiO}_{2}$ thin films under different annealing process, the paper is in accordance with the annealing temperature was $400^{\circ} \mathrm{C}, 450^{\circ} \mathrm{C}, 500^{\circ} \mathrm{C}, 550^{\circ} \mathrm{C}$ experimental process of $\mathrm{TiO}_{2}$ annealing.

\subsection{Pore-Forming Agent}

In order to study the effects of pore-forming agent to $\mathrm{TiO}_{2}$ film electrode spectral characteristics and optical properties, the molecular weight of $400 \mathrm{~g} / \mathrm{moL}, 2000 \mathrm{~g} / \mathrm{moL}, 4000 \mathrm{~g} / \mathrm{moL}$ PEG as the pore-forming agent to prepare $\mathrm{TiO}_{2}$ sol-gel.

\section{Results and Discussion}

\subsection{Observing the Morphology of $\mathrm{TiO}_{2}$ Films}

With a scanning electron microscope (Hitachi Company, type S-570) to observe the surface morphology, Voltage of $20 \mathrm{kV}, \mathrm{TiO}_{2}$ ultrafine particles in the sol is $\mathrm{TiO}_{2}$ nanometer powder added $\mathrm{P} 25$ when preparing the slurry. Seen in Figure 1 ( $\mathrm{TiO}_{2}$ film is a 500 times magnification scanning electron micrographs), the particles are very small, the specific surface area is large and surface roughness is high large, the film surface is uniformly smooth, particle agglomeration less. Interconnection between nanoparticles and the electrode constituting a sponge-like structure, so that there is good electrical contact between the nanocrystals, such injection of electrons from one particle to become another particle easier diafiltration. Between the spherical particles have numerous pores, and is conducive to the electronic transmission of the electrolyte; redox couple can penetrate into the porous film nanocrystal line semiconductor electrode, the dye molecules can be effectively oxidized regenerated.

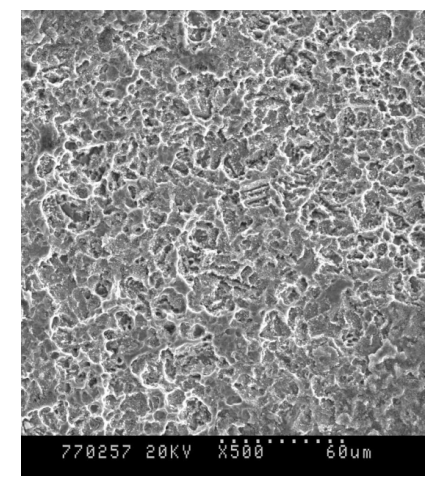

Figure 1. SEM images of titania films $(\times 500)$. 


\subsection{Structural Testing of $\mathrm{TiO}_{2}$ Film}

Using the RIGAKU D/MAX-2200 type PC X-ray diffraction of the phase of the sample were measured for the $\mathrm{Cu}$ target radiation. $\lambda=0.15418 \mathrm{~nm}$, the working voltage of $40 \mathrm{kV}$, current of $30 \mathrm{~mA}$, the scanning range of $10^{\circ}-80^{\circ}$, the scanning speed was $20^{\circ} \mathrm{C} / \mathrm{min}$.

\subsection{Effect of Annealing Temperature on Cell Performance}

Figure 2 is X-ray diffraction pattern of $\mathrm{TiO}_{2}$ film sintered in $500^{\circ} \mathrm{C}$. Through calculation, the proportion of anatase and rutile from the before 82:18 becomes 77:23. Rutile content increased. Rutile $\mathrm{TiO}_{2}$ surface electron-hole pairs combine speed anatase faster than the relative anatase, its optical performance is poor. However, the band gap of rutile $\mathrm{TiO}_{2}$ is $3.0 \mathrm{eV}$, the band gap of anatase $\mathrm{TiO}_{2}$ is $3.2 \mathrm{eV}$, therefore, photosensitivity stronger than rutile $\mathrm{TiO}_{2}$ anatase. And found that due to the different crystal structures, can effectively promote the anatase crystals photoinduced charge separation of electrons and holes (mixed grain effect). Therefore, the appropriate content of rutile is advantageous. Scherrer formula calculation results show that the average grain size of anatase $\mathrm{TiO}_{2}$ nanoscale, which is about $18.9 \mathrm{~nm}$, Compared to $18.6 \mathrm{~nm}$ before the sintering, only minor increases, grain growth is not obvious.

Figure 3 and Figure 4 are the effect of annealing temperature on the short-circuit current and open circuit voltage of the DSSCs respectively.

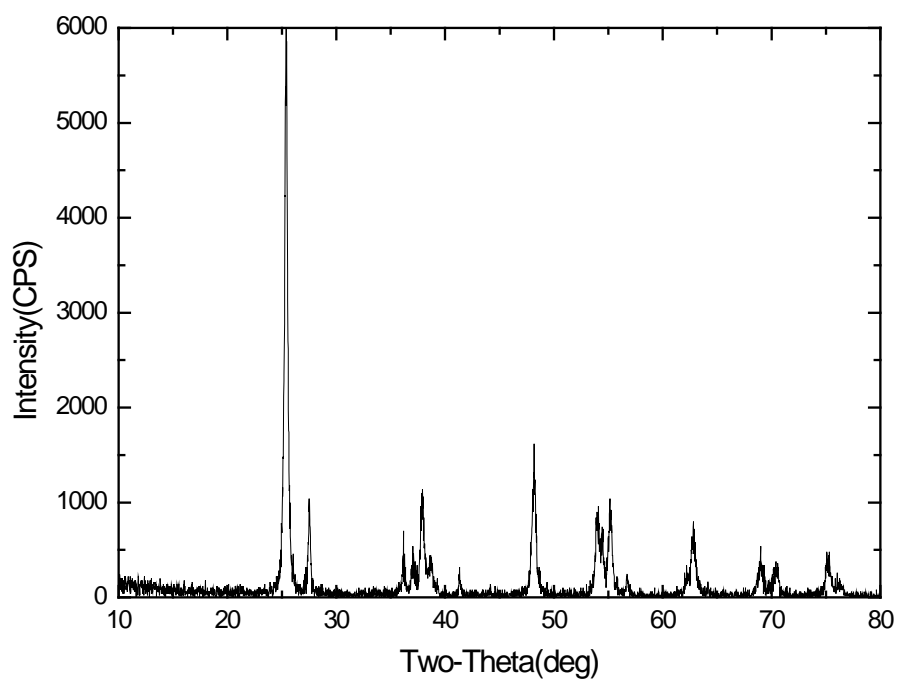

Figure 2. XRD patterns of titania films.

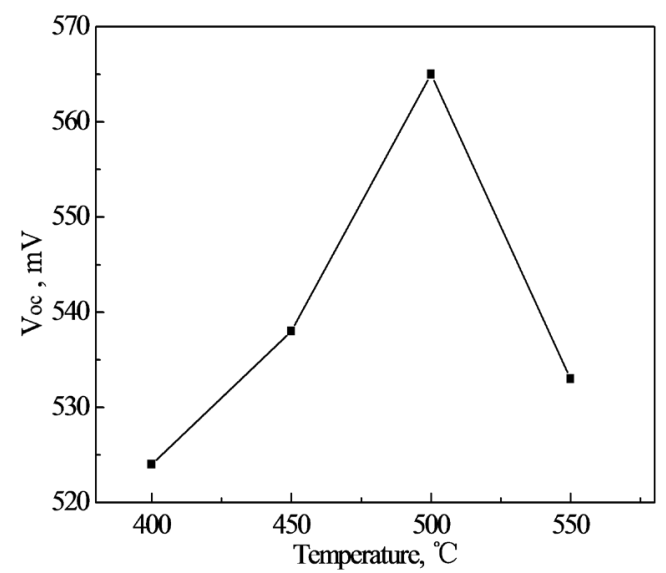

Figure 3. Relationship between the annealing temperature and the open circuit voltage. 


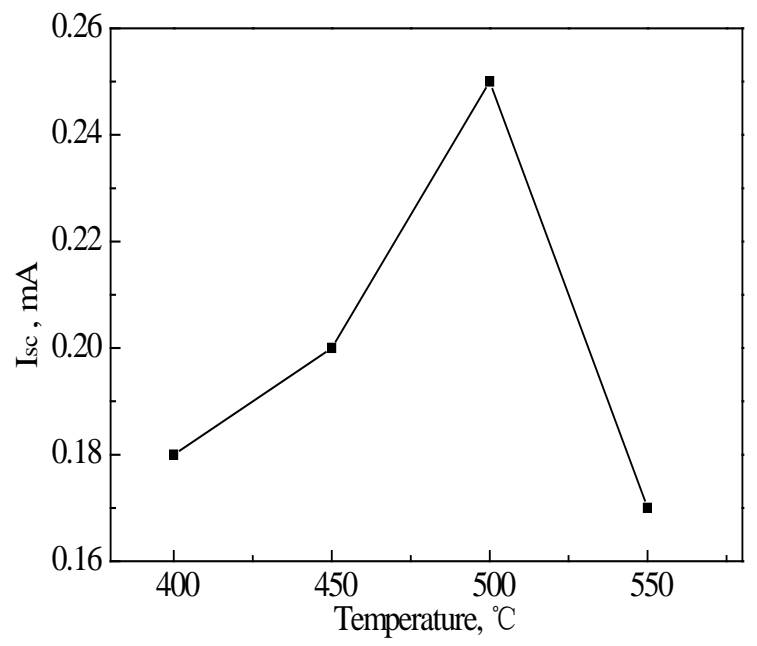

Figure 4. Relationship annealing temperature and short-circuit current.

As can be seen from the two figures, when the annealing temperature increased from $400^{\circ} \mathrm{C}$ to $500^{\circ} \mathrm{C}$, the cell's open-circuit voltage and short circuit current were increased, improved optical performance of the battery; When the annealing temperature reaches $500^{\circ} \mathrm{C}$, the short-circuit current and open circuit voltage reaches a maximum, respectively $0.60 \mathrm{~mA}$ and $0.6888 \mathrm{~V}$; When the temperature continues to rise, the cell open circuit voltage and short circuit current is reduced. This shows that the annealing temperature on the optical properties of $\mathrm{TiO}_{2}$ thin film electrode is large, and there is an optimum annealing temperature. This is because the $\mathrm{TiO}_{2}$ film $400^{\circ} \mathrm{C}$ annealed, the organic film is not completely removed, it will clog the holes in the $\mathrm{TiO}_{2}$ thin film, so the specific surface area decreased, the pore size decreases, reducing the dye adsorbed $\mathrm{TiO}_{2}$ film, reduces the cell short-circuit current.

Because the dye molecules is larger than the $\mathrm{I}_{3}^{-}$, the $\mathrm{I}_{3}^{-}$in direct contact with the $\mathrm{TiO}_{2}$ particles, the reaction tends to occur, $\mathrm{I}_{3}^{-}+2 \mathrm{e}_{\mathrm{cb}}^{-}\left(\mathrm{TiO}_{2}\right) \rightarrow 3 \mathrm{I}^{-}$, reducing the open circuit voltage. However, when the annealing temperature is too high, the pore size increases. When the pore size is too large, the average distance between particles of $\mathrm{TiO}_{2}$ increases, the decrease in the efficiency of electron transport, electron injection flux decline, Shortcircuit current is reduced. From the test results, when the annealing temperature of $500^{\circ} \mathrm{C}$, the cell current and voltage reaches the highest value.

\subsection{Effect of Pore-Forming Agent Molecular Weight on the Performance of the Cell}

The $\mathrm{TiO}_{2}$ film electrodes prepared for optical performance testing, test results obtained are shown in Table 1 .

As can be seen from the table, when adding a molecular weight of 4000 PEG, open circuit voltage and short circuit current density of $\mathrm{TiO}_{2}$ thin film electrodes were $0.5297 \mathrm{~V}$ and $0.35 \mathrm{~mA} / \mathrm{cm}^{2}$. When adding a molecular weight of PEG 400, the open circuit voltage and short circuit current density of $\mathrm{TiO}_{2}$ thin film electrodes were $0.5864 \mathrm{~V}$ and $0.49 \mathrm{~mA} / \mathrm{cm}^{2}$, adding molecular weight is 2000PEG, open circuit voltage and short circuit current density was $0.6888 \mathrm{~V}$ and $0.60 \mathrm{~mA} / \mathrm{cm}^{2}, \mathrm{TiO}_{2}$ film electrode has a better optical performance. This may be because when the molecular weight is 400 PEG decomposition annealing holes left too dense, thus the adsorption properties of the film do not substantially increase. When the molecular weight is 4000, PEG left decomposition annealing holes are too loose, in the annealing process and the film will be off, thus affecting the adsorption capacity of $\mathrm{TiO}_{2}$ film on dye. When the molecular weight is 2000, PEG annealing decomposition holes left loose moderate, $\mathrm{TiO}_{2}$ thin film on the adsorption capacity of the dye is better.

From the testing results, when adding a molecular weight of 2000 PEG, the cell has good photoelectric performance. The electrode assembly into the cell, photoelectric conversion efficiency test. When the incident light intensity is $73.1 \mathrm{~mW} / \mathrm{cm}^{2}$, through $I V$ curves to calculate the maximum output power $\left(P_{\max }\right)$, using the formula:

$$
\eta=\frac{P_{\max }}{P_{\text {in }}}=\frac{V_{m p} I_{m p}}{P_{\text {in }}} \times 100 \%
$$




$$
\eta=\frac{f f V_{o c} I_{s c}}{P_{\text {in }}} \times 100 \%
$$

Calculate the photoelectric conversion efficiency $(\eta)$ and fill factor $(f f)$ of $0.37 \%$ and $0.214 \%$ respectively.

Figure 5 is a $\mathrm{TiO}_{2}$ thin film ultraviolet-visible absorption spectra, using PEG2000 as hole-forming agent. As can be seen from the figure, compared to pure $\mathrm{TiO}_{2}$ films, spectra of $\mathrm{TiO}_{2}$ films PEG2000 added in the shape of the curve after a changes, in the visible range of the light absorption has increased, expand the scope of the $\mathrm{TiO}_{2}$ nanoparticles absorb visible light direction. In addition, the absorption peak moves to long wave direction, A small amount of red shift of spectrum, The light absorption properties increased.

\subsection{Scanning Electron Microscope Observation}

The SEM photos of the $\mathrm{TiO}_{2}$ film electrode is presented in Figure 6 and Figure 7 without PEG and join the PEG2000 prepared by sol-gel method, magnification 500 times. As can be seen from the figure, compared with the $\mathrm{TiO}_{2}$ film without PEG, after adding PEG2000, $\mathrm{TiO}_{2}$ nanoparticles and the surface of $\mathrm{TiO}_{2}$ film are bonded together to form a network structure, which is more conducive to electron transport, improve optical performance.

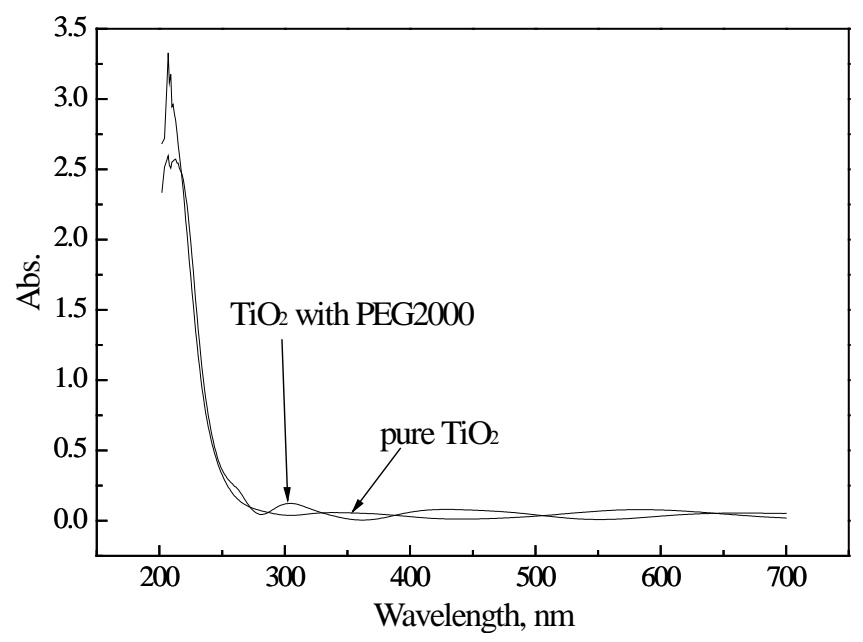

Figure 5. Ultraviolet-visible absorption spectra of $\mathrm{TiO}_{2}$ thin film with PEG2000 and pure $\mathrm{TiO}_{2}$ films.

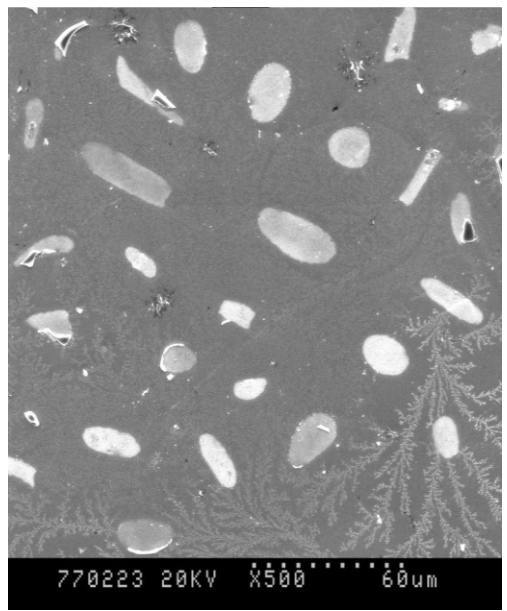

Figure 6. SEM diagram of $\mathrm{TiO}_{2}$ films without PEG ( $\times 500$ times). 


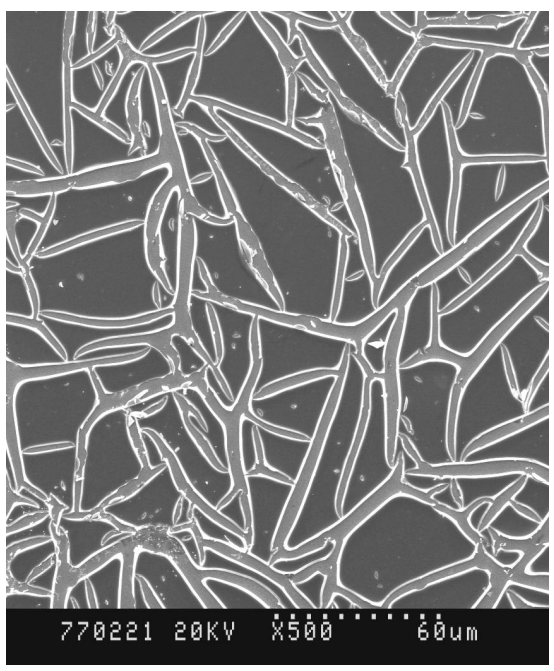

Figure 7. SEM diagram of $\mathrm{TiO}_{2}$ films with PEG2000 (×500 times).

Table 1. Photoelectric properties of $\mathrm{TiO}_{2}$ films under different molecular weight PEG.

\begin{tabular}{ccc}
\hline Molecular weight $(\mathrm{g} / \mathrm{moL})$ & Open circuit voltage $(\mathrm{V})$ & Short circuit current density $\left(\mathrm{mA} / \mathrm{cm}^{2}\right)$ \\
\hline 4000 & 0.5297 & 0.35 \\
2000 & 0.6888 & 0.60 \\
400 & 0.5864 & 0.49 \\
\hline
\end{tabular}

\section{Conclusions}

This paper focuses on the annealing temperature, pore-forming agent (PEG) molecular weight of the two parameters on the dye-sensitized $\mathrm{TiO}_{2}$ thin film photovoltaic solar cell performance, and with the X-ray diffraction, scanning electron microscopy, UV-visible spectrophotometer and other modern detection methods on the crystalline structure, surface morphology and optical properties of $\mathrm{TiO}_{2}$ thin films were characterized by the proceeds from the experimental results are as follows:

1) The effect of annealing temperature on the structure and optical properties of $\mathrm{TiO}_{2}$ thin films. Experimental results show that the annealing temperature of $500^{\circ} \mathrm{C}, \mathrm{TiO}_{2}$ film electrode has good optical properties;

2) By examining the different molecular weight PEG effect on the $\mathrm{TiO}_{2}$ thin film's surface morphology, optical absorption properties, found that when adding PEG of molecular weight 2000, the $\mathrm{TiO}_{2}$ thin film electrode has the best performance. The experiment on the annealing temperature is $500^{\circ} \mathrm{C}$; process parameter added $0.5 \mathrm{~g}$ PEG, preparing the filling factor to be 0.39 , the photoelectric conversion efficiency of dye-sensitized solar cells for $0.22 \%$.

\section{References}

[1] O’Regan, B. and Gratzel, M. (1991) A Low Cost, High Efficiency Solar Cell Based on Dye-Sensitized Colloidal TiO 2 Films. Nature, 353, 737-740. http://dx.doi.org/10.1038/353737a0

[2] Nazeeruddin, M.K., Kay, A. and Gratzel, M. (1993) Conversion of Light to Electricity by cis-X-bis-(2,2'-bipyridyl4,4'-dicarboxylat-e) Ruthenium (II): Charge-Transfer Sensitizers (X = Cl-, Br-, I-, CN- and SCN-) on Nanocrys-Talline Titanium Dioxide Electrodes. Journal of the American Chemical Society, 115, 6382-6390. http://dx.doi.org/10.1021/ja00067a063

[3] Nazeeruddin, M.K., Comte, P. and Gratzel, M. (2001) Engineering of Efficient Panchromatic Sensitizers for Nanoc Rystalline $\mathrm{TiO}_{2}$-Based Solar Cells. Journal of the American Chemical Society, 123, 1613-1624. http://dx.doi.org/10.1021/ja003299u

[4] Yasuo, C., Ashrafui, I., Yuki, W., et al. (2006) Dye-Sensitized Solar Cells with Conversion Efficiency of 11.1\%. Japanese Journal of Applied Physics, 45, 638-640. 
Scientific Research Publishing (SCIRP) is one of the largest Open Access journal publishers. It is currently publishing more than 200 open access, online, peer-reviewed journals covering a wide range of academic disciplines. SCIRP serves the worldwide academic communities and contributes to the progress and application of science with its publication.

Other selected journals from SCIRP are listed as below. Submit your manuscript to us via either submit@scirp.org or Online Submission Portal.
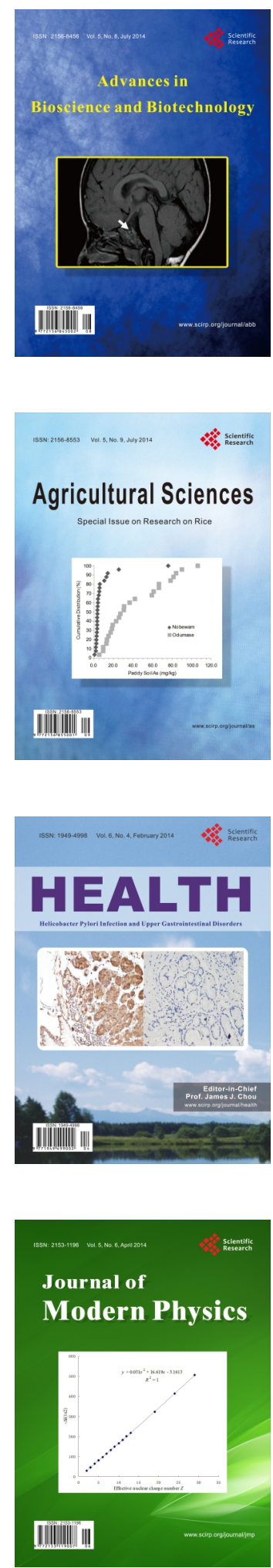
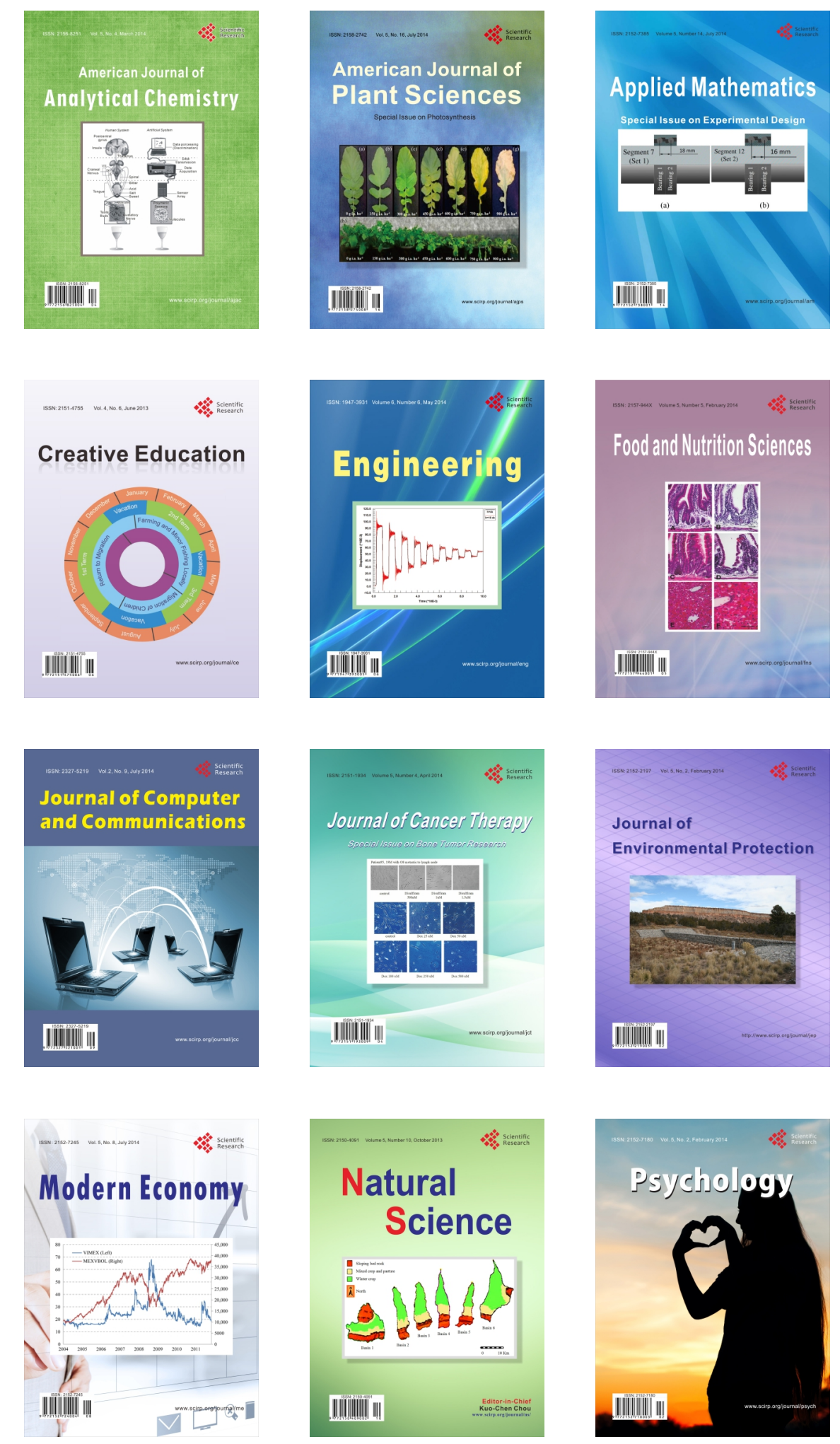